\title{
The comparison of the effects of etanercept, cyclosporine $A$ and triamcinolon acetonide on Th17 in experimental autoimmune uveitis
}

\author{
Tamer Demir ${ }^{1}$, Jülide Kurt Keleş ${ }^{2}$, Bengü Çobanoğlu ${ }^{3}$ and Burak Turgut ${ }^{4}$ \\ ${ }^{1}$ Department of Ophthalmology, Faculty of Medicine, Firat University, Elazig, Turkey \\ ${ }^{2}$ Ophthalmology Clinic, Malatya State Hospital, Malatya, Turkey \\ ${ }^{3}$ Department of Ophthalmology, Faculty of Medicine, Medeniyet University, Istanbul, Turkey \\ ${ }^{4}$ Department of Ophthalmology, Faculty of Medicine, Firat University, Elazig, Turkey
}

\begin{abstract}
Background: To investigate the effect of etanercept on Th17, and to compare its effect with those of cyclosporine A (CsA) and triamcinolon acetonide (TA) in experimental autoimmune uveitis (EAU) model.

Materials and methods: Thirty five guinea pigs were assigned to five groups of seven animals in each. The single eyes of all animals in the groups except the control group were administered intravitreally $1 \mathrm{mg} / \mathrm{ml}$ conconavalin A to induce the EAU. The animals in the control group were not also given any treatment. On the 14 th day, after confirmation of uveitis, the eyes in sham group, etanercept and TA groups were received single dose intravitreally $0.1 \mathrm{ml} \mathrm{saline,} 2 \mathrm{mg} / 0.1 \mathrm{ml}$ etanercept and $4 \mathrm{mg} / 0.1 \mathrm{ml} \mathrm{TA}$, respectively. The animals in the CsA group were administred intravitreally $100 \mu \mathrm{g} / 0.1 \mathrm{ml} \mathrm{CsA}$ weekly. At the end of 6th week following the drug administrations, the globes were excised. The immunostaining intensities and diffusenesses of Th17 were evaluated immunohistobiochemically.

Results: Th17 immunostaining intensity was higher in sham group than those in the control and treatments groups $(\mathrm{p}<0.001)$. There was no statistically significant difference among immunostaining intensities in treatment groups ( $p>0.05$ ). The immunostaining diffuseness of Th17 in the sham group was higher compared that of the control group $(\mathrm{p}<0.01$ ). When compared with each treatment groups, immunostaining diffuseness was found to be raised in the sham group ( $<0.05$ ). There was no significant difference between the treatment groups $(p>0.05)$.
\end{abstract}

Conclusion: Intravitreal etanercept, CsA and TA equally decreased Th17 immunostaining intensity.

\section{Introduction}

Uveitis, the inflammatory disease of the iris, ciliary body, and choroidea can cause to permanent ocular damage and visual loss. Its exact etiopathogenesis is not known. However, it is well known that pro-inflammatory cytokines including interleukin (IL)-1, IL-6, and tumor necrosis factor-alpha (TNF- $\alpha$ ) play in important role in uveitis [1-3].

Currently, there is no effective treatment for the disease. Corticosteroids and some immunosuppressive drugs have been commonly used in the treatment of uveitis. However, the systemical and ocular side effects arising from long-term and high-dose administration of especially corticosteroids limit the use of them [1-4]. Thus, researchers have been searched new drugs with fewer side effects and greater efficacy to be use in the treatment of uveitis. As the TNF- $a$ is one of the pro-inflammatory cytokines which play in key role in the pathogenesis of various uveitis types, currently, the investigation of the usage of anti-TNF agents for this purpose is very popular.

Etanercept is a soluble fusion protein composed of the extracellular ligand-binding portion of human TNF receptor p75 and the Fc portion of human IgG1. It inhibits the action of both TNFa and TNF $\beta$. Etanercept has been used in the treatment of some autoimmune diseases such as rhomaid artritis, adult Still's disease, ankylosing spondylitis [5-7]. Recent studies have been shown that systemically etanercept is efficious in the treatment in both the patients with chronic uveitis and experimental autoimmune uveitis (EAU) [8-10]. In a recent experimental study, it was also demonstrated that intravitreal etanercept was effective for the treatment of EAU [11]. Because of the adverse effects of systemic TNF- $\alpha$ inhibition, intravitreal administration of the drug may be more adequate to avoid these side effects.

In animal models on immune-mediated diseases, it has been demostrated that the number of T-helper type 17 cell (Th17) increased in active uveitis and scleritis while it reduced after treatment. IL-17 is produced by Th17 cells and increased in EAU and upregulated TNF- $\alpha$. Th17 cells and IL-17 play a critical role in the pathogenesis of the

Correspondence to: BurakTURGUT, MD, Associate Professor of Ophthalmology, Firat University Faculty of Medicine, Department of Ophthalmology, 23119, Elazig, Turkey, Tel: +90 424 2333555; Fax: +90 424 2388096; E-mail: drburakturgut@gmail.com

Key words: etanercept, cyclosporine A, triamcinolon acetonide, experimental autoimmune uveitis, Th17

Received: April 03, 2016; Accepted: April 29, 2016; Published: May 04, 2016 
intraocular inflammation and uveitis in humans. Anti-mouse IL-17blocking antibodies and anti-TNF- $\alpha$ antibodies have been suppressed intraocular inflammation in experimental uveitis models [12-21].

In this study, we aimed to investigate the effect of etanercept on Th17, and to compare its effect with those of cyclosporine A (CsA) and triamcinolon acetonide (TA) in EAU.

\section{Materials and methods}

\section{Animals and study ethics}

The study included 35 male albino guinea pigs, of mean weight 400 g. Throughout the study, the experiments were kept in the experimental research center at Firat University. The animals were housed in wirebottomed cages at room temperature on a 12-hour light-dark cycle. All animals were fed with standard guinea pig chow, but were given only water 12 hours before surgery. This study was carried out on one eye of each experiment, with approval from the institutional ethics committee of Firat University. All procedures were performed with strict adherence to the guidelines for animal care and experimentation prepared by the Association for Research in Vision and Ophthalmology and Guidelines for the Housing of Rats in Scientific Institutions.

\section{Groups}

The animals were randomly allocated to five groups, with seven guinea pigs in each group:

Group 1 (control group) included the animals which were not operated on and did not receive any treatment.

Group 2 (sham group) included the animals in which induction of EAU was performed and which received single dose intravitreally $0.1 \mathrm{ml}$ saline.

Group 3 (etanercept group) included the experiments in which induction of EAU was performed and which received intravitreally single dose $2 \mathrm{mg} / 0.1 \mathrm{ml}$ etanercept (Enbrel, Wyeth Pharmaceuticals, Philadelphia, PA, USA).

Group 4 (cyclosporine A group) included the experiments in which induction of EAU was performed and which received intravitreally 100 $\mu \mathrm{g} / 0.1 \mathrm{ml}$ cyclosporin A (Sandimmun $50 \mathrm{mg} / \mathrm{ml}$ ampoule, Novartis Pharma AG, Basel, Switzerland) weekly.

Group 5 (triamcinolon acetonide) included the experiments in which induction of EAU was performed and which received intravitreally single dose $4 \mathrm{mg} / 0.1 \mathrm{ml}$ triamcinolone acetonide (Kenacort A $40 \mathrm{mg}$ / $\mathrm{ml}$ ampoule, Bristol Myers Squibb Co., Princeton, NJ, USA).

At the end of 6th week following the drug administrations, the globes were enucleated after induction of analgesia and anesthesia.

\section{Induction of experimental autoimmune uveitis}

The animals in the groups other than the control group were injected intravitreally with concanavalin A (Sigma Chemical Co, St Louis, MO) $1 \mathrm{mg} / \mathrm{mL}$ in the right eye only. Drug administration was started when uveitis-like inflammation developed 2 weeks later. Topical antibiotic drops were instilled to eyes.

\section{Anesthetic technique}

The animals were injected with a combination of intramuscular ketamine hydrochloride $50 \mathrm{mg} / \mathrm{kg}$ (Ketalar , Eczacıbaşı, Turkey) and xylazine hydrochloride $5 \mathrm{mg} / \mathrm{kg}$ (Rompun ${ }^{\circledR}$, Bayer, Turkey) to induce anesthesia and analgesia.

\section{Surgical technique}

After induction of anesthesia and analgesia, $1 \mathrm{mg} / 0.1 \mathrm{~mL}$ concanavalin A was injected using a 30-gauge needle into the right eye only, except in the animals in the control group. At the end of the second week, slit-lamp biomicroscopy revealed flare in the anterior chamber, moderate cell numbers, fibrin behind the lens, and moderate cataract. After development of uveitis was confirmed clinically, the sham and treatment groups were given intravitreally injections at the end of the second week. At the end of $6^{\text {th }}$ week, the eyes of the experiments were enucleated. The globes were sent to the pathology laboratory for the evaluation of the immunostaining intensities and diffusenesses of Th17.

\section{Histopathologic methods}

The enucleated eyes were immediately stored in special fixation solution ( $4 \%$ paraformaldehyde) for 24 hours at $4^{\circ} \mathrm{C}$. They were then transferred into $70 \%$ alcohol and stored at $4^{\circ} \mathrm{C}$ until embedding in paraffin. The slides with ring-shaped and $5 \mu \mathrm{m}$ thickness including retina, choroid and sclera were prepared for immunohistochemical staining. After the slides were paraffinized and rehydrated, they were quenched in $0.3 \%$ hydrogen peroxide for $5 \mathrm{~min}$ to prevent the activity of endogenous peroxidases. The slides were washed with distilled water and immersed in $10 \mathrm{mM}$ sodium citrate buffer for $5 \mathrm{~min}(\mathrm{pH}$ 6.0) and heated for $15 \mathrm{~min}$ in a microwave oven (650 milliwatts). Then, the sections were incubated in tris buffer solution (TBS) for 5 min with primer antibody (IL-17, Santa Cruz Biotechnology, Santa Cruz, CA). Applying in a humid environment at $28^{\circ} \mathrm{C}$ was allowed to stand for 30 minutes and they were washed with TBS. The secondary antibody marked with biotin was applied for 15 minutes and washed again with TBS. After incubating for 10 minutes with streptavidin peroxidase conjugate, it was washed again with TBS. AEC chromogen Zealand Mayers for 15 minutes as opposed floor paint was used to hold sections with hematoxylin. Preparations finally closed with special sealing material were randomly evaluated with using $\times 400$ objective of a standard light microscope (BX50 photomicroscope; Olympus Corporation, Tokyo, Japan). Digital photographs were taken with the camera of the same microscope in the X400 and X1000 magnification.

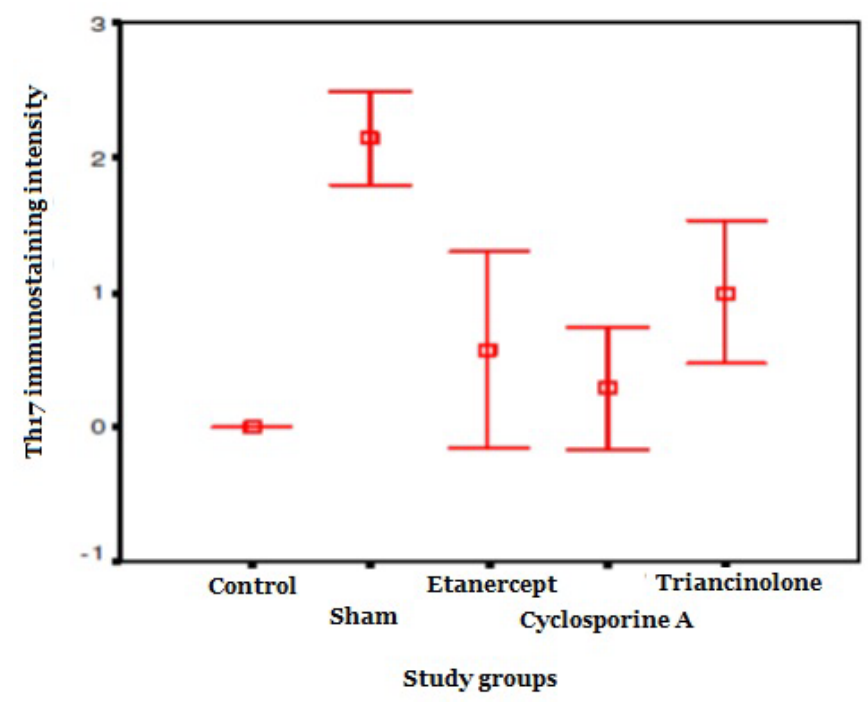

Figure 1. The immunostaining intensity of Th17 in the study groups. 


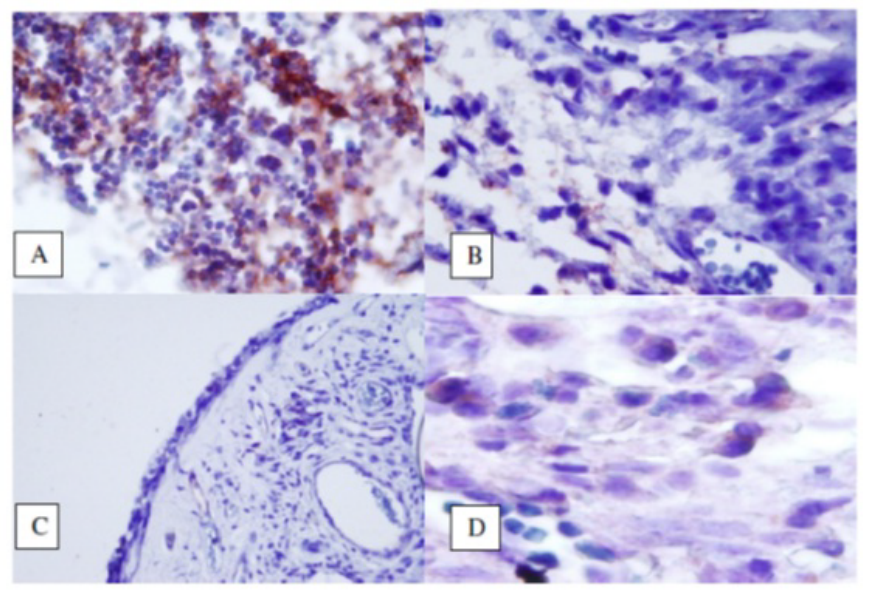

Figure 2. The microphotographs demonstrating the immunostaining intensity and diffuseness of Th17 in the sham (A), etanercept (B), cyclosporine (C) and triamcinolone (D) groups.

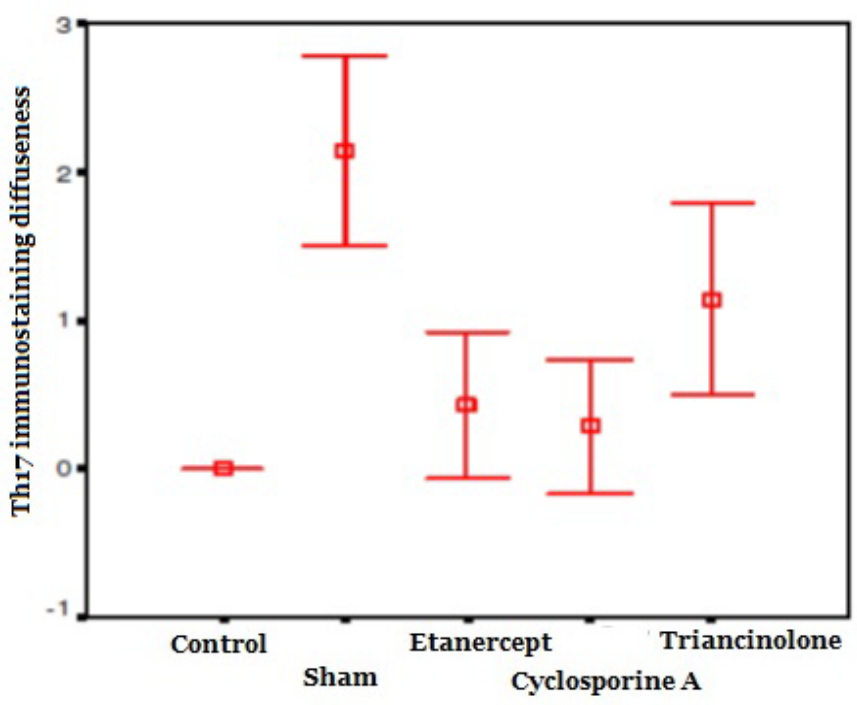

Study groups

Figure 3. The immunostaining diffuseness of Th17 in the study groups.

The edema, congestion, polymorph nuclear (PMN) and mononuclear cell infiltration (MNC) in the tissues were evaluated. The intensity and diffuseness of immunohistochemical staining of Th17 cells using IL-17 antibody were also evaluated.

For immunostaining intensity of Th17 cells, Four-point scale was used:

- Grade 0: no staining

- Grade 1: mild staining

- $\quad$ Grade 2: moderate staining

- $\quad$ Grade 3: strong staining

Immunostaining diffuseness of Th17 cells was evaluated using the percentage of positive staining cells:

- Grade 0: for negative

- Grade 1: for $1-33 \%$ positive
- Grade 2: for $34-66 \%$ positive

- Grade 3: for $67-100 \%$ positive

\section{Histopathologic confirmation of EAU}

Histopathologic examination revealed heavy infiltration of inflammatory cells, edema, and fibrosis in the retina and ciliary body, as well as proliferation in the ciliary epithelium after intravitreal injection of concanavalin A. These signs were interpreted as evidence of induction of uveitis (sham group). None of these histopathologic changes were observed in the control group. Histopathologic examination revealed mild inflammatory cellular infiltration including lymphocytes and rarely eosinophils, edema and fibrosis in the iris and ciliary body in the treatment groups.

\section{Statistical analyses}

The means ( \pm standard deviations) of the data obtained were calculated. The statistical analysis was carried out using the Statistical Package for Social Sciences version 13 (SPSS Inc, Chicago, IL). Analysis of variance was carried out for multiple comparisons using the Kruskal-Wallis test, and the Mann-Whitney U test was used for dual comparisons between groups. A P value 0,0.05 was accepted as being statistically significant.

\section{Results}

The edema in the sham group was found to be increased compared to the control group $(\mathrm{p}<0.01)$. The edema in etanercept and TA groups were not significantly different from that in the sham group $(\mathrm{p}>0.05)$. It was found that the edema in CsA group was lower when compared with the sham group $(p<0.05)$ and was the nearest value to that in the control group.

It was observed that the tissue congestion in the retina and choroid was different in the study groups $(\mathrm{p}<0.01)$. The congestion in the sham group was higher compared with the control group $(\mathrm{p}<0.01)$. The congestion in the treatment groups was not different than that in the sham group ( $p>0.05$ ). Additionally, it was found that the congestion in the treatments groups was not different than each other $(p>0.05)$.

The mean MNC infiltration in the sham group were higher than the control group $(\mathrm{p}<0.01)$. MNC infiltration in the treatment groups diminished compared to the sham group $(\mathrm{p}<0.01)$. The difference in MNC among the treatment groups was not statistically significant ( $\mathrm{p}>0.05)$.

The mean PMN infiltration in the sham group were higher than the control group $(\mathrm{p}<0.01)$. PMN infiltration in the etanercept and TA groups was not different compared to the that in the sham group $(\mathrm{p}>0.05)$. PMN infiltration in the CsA group was higher than that in the sham group $(\mathrm{p}<0.05)$.

\section{The immunostaining intensity of Th17}

Th17 immunostaining intensity was higher in sham group than those in the control and treatments groups $(\mathrm{p}<0.001)$. It was observed that the immunostaining intensity in the sham group was higher than those of the treatment groups $(\mathrm{p}<0.01)$. There was no significantly difference among the paired comparisons of the immunostaining intensities in the treatment groups ( $>0.05$ ). It was observed that Th17 immunostaining intensity in the etanercept and CsA groups was closer to the that in the control group, while the immunostaining intensity in the triamcinolone group was higher than that in the control $(\mathrm{p}<0.01)$. 
Table 1. The levels of immunostaining intensity and diffuseness in the study groups.

\begin{tabular}{|l|c|c|c|c|}
\hline & Control & Sham & Etanercept & Cyclosporine A \\
\hline $\begin{array}{l}\text { Th17 } \\
\text { intensity }\end{array}$ & $0.00 \pm 0.00^{* * *}$ & $2.14 \pm 0.37$ & $0.57 \pm 0.78^{* *}$ & $0.29 \pm 0.48^{* *}$ \\
\hline Th17 diffuseness & $0.0 \pm 0.00^{* *}$ & $2.14 \pm 0.69$ & $0.43 \pm 0.53 * *$ & $0.29 \pm 0.48^{* *}$ \\
\hline
\end{tabular}

Compared to the sham group: ${ }^{*} p<0.05 ; * *_{p}<0.01 ; * * * p<0.001$

When the drug group compared with Th17 concentration was elevated in sham group There was no statistical significantly difference among immunostaining intensities in treatment groups $(\mathrm{p}>0.05)$.

\section{The immunostaining diffuseness of Th17}

The immunostaining diffuseness of Th17 in the sham group was higher compared that of the control group $(p<0.01)$. When compared with each treatment groups, immunostaining diffuseness was found to be raised in the sham group $(\mathrm{p}<0.05)$. There was no significant difference between the treatment groups $(p>0.05)$. In the CsA and etanercept groups it was close to the control group ( $p>0.05)$, whileas the immunostaining diffuseness of Th17 in the TA group was found to be higher than that in the control group $(\mathrm{p}<0.01)$.

\section{Discussion}

Experimental autoimmune uveitis has been developed by injecting concanavalin a, retinal S antigen, rhodopsin, recoverin, and interphotoreceptorbinding protein (IRBP) in various experimental studies [22-24]. In the present study, we preferred concanavalin a for the induction of the uveitis because of its easy availability. Concanavalin a is a non-specific inflammatory agent of the lectin group. It has the mitogenic effect on $\mathrm{T}$ cells and some B cells $[23,24]$. It causes a longlasting inflammatory response including the periods of aggravation and alleviation. Inflammatory response to concanavalin a is clinically characterized with cells in anterior chamber and vitreous, formation of posterior synechia, and complicated cataract. These characteristics are very similar to those of human uveitis $[23,24]$.

In our study, the histopathologic examination for the sham group revealed heavy inflammatory cell infiltration, edema, congestion in the retina and ciliary body, proliferation in the ciliary epithelium after the intravitreal injection of concanavalin a. These signs were considered as evidence of the induction of uveitis. In this study, we histopathologically noted that inflammatory cell infiltration in uveal tissue was lower in all treatment groups compared to the sham group.

Although many cytokines contributed to uveitis, minority of them play significant roles. Recent studies have shown that a new $\mathrm{T}$ helper subset that produces IL-17 (Th17) is also involved in the development of EAU $[25,26]$. TNF is a local paracrine and autocrine regulator cytokine for inflammatory cells. TNF- $\alpha$ stimulates mononuclear phagocytes as well as other cell types that produce IL-1, IL-6 and chemokines, and induces the migration of PMN leukocytes [24,26,27]. The animal models has been demonstrated that the number of T-helper type 17 cell (Th17) increased in active uveitis and scleritis while it reduced after treatment. IL-17 is produced by Th17 cells and elevated in EAU and upregulated TNF- $\alpha$. Thus, TNF- $\alpha$, Th17 cells and IL-17 play a critical role in the development of the intraocular inflammation in uveitis in humans. Additionally, anti-mouse IL-17-blocking antibodies and antiTNF- $\alpha$ antibodies have been suppressed intraocular inflammation in experimental uveitis models [12-21].

Interleukin 17 is a pro-inflammatory cytokine composed of glycosylated homodimers weighted $20-30 \mathrm{kDa}$. It binds to a type I cell surface receptor called IL-17R. IL-17A, B, C, D, E and F subtypes of IL17 have been described. IL-17 induces the production of TNF- $\alpha$, IL-1 $\beta$, IL6, IL-8 [28-33]. IL-17 acts as a potent mediator in delayed-type reactions by increasing chemokine production in various tissues. In promoting inflammation, IL-17 has been demonstrated to act synergistically with TNF and IL-1. This can result in various autoimmune disorders with chronic inflammation [28-30]. It was known in EAU that IL-17 elevated and increased the synthesis of TNF- $\alpha$ in retinal cells and that IL-17 synthesis was suppressed by the synthesis of IL-27 and IFN- $\gamma$ [13].

Recent studies demonstrated that blood levels of IL-23, IL-17 and IFN- $\gamma$ simultaneously increased in intraocular inflammation in Behcet's disease [34]. Luger et al reported that the presence of Th17 cells and a dominant role of Th1 cells and in inflammation in the EAU $[26,35]$. In our study, we demonstrated that the immunostaining intensity and diffuseness of Th17 cell were raised in the sham group. This shows that Th17 plays in role in inflammatory processes in uveitis.

Etanercept is a soluble fusion protein produced by recombinant DNA of the extracellular ligand-binding portion of human TNF receptor p75 and the Fc portion of human IgG1. This agent inhibits the action of both TNF- $\alpha$ and TNF- $\beta$, important pro-inflammatory cytokines [511]. Etanercept is a large molecule with a molecular weight of $150 \mathrm{kDa}$. It binds to TNF- $\alpha$ and decreases its effect in disorders involving excess inflammation in humans and animals, including autoimmune diseases such as ankylosing spondylitis, juvenile rheumatoid arthritis, psoriasis, psoriatic arthritis, rheumatoid arthritis, and potentially, in various disorders mediated by excess TNF- $\alpha$ such as uveitis $[5-11,36]$.

It has been demonstrated that Th17 level and Th1/Th2 ratio significantly decreased following the treatment in the patients with rheumatoid arthritis and also IL-17 level reduced in patients with psoriasis with etanercept $[37,38]$. In another study in psoriatic patients, etanercept suppressed the proliferation of Th17 [39]. In a rat EAU model, it was showed that TNF- $\alpha$ antagonists decreased the severity of uveitis [40]. In our study, etanercept also reduced the infiltration of Th17 and this result is compatible with that of former study. In a recent study, Busch et al investigated the effect of systemic or local TNF- $\alpha$ inhibition with etanercept on EAU. They found that after systemic treatment with etanercept in the afferent phase, EAU disease scores, IRBP-specific cell proliferation, and production of Th1, Th2, and Th17 cytokines were reduced. EAU also improved after intravitreal etanercept treatment in the afferent phase [11].

Cyclosporine A is a T cell-specific immunosuppressant, which inhibits the production of IL-2. CsA binds to intracellular cyclophilin and this complex inhibits calcineurin which plays a critical role in IL-2 gene transcription [41]. CsA has been shown to be effective in the treatment of immune-mediated ocular diseases [42-46]. It prevented disease process in the retinal S-Ag induced EAU model [46].

After it has been shown that CsA prevented the development of EAU, it has been commonly used especially in the treatment of uveitis threatening vision in humans. CsA affects the early phase of the immune response via the blockade of the synthesis and release of IL- 1 from by macrophages and IL- 2 from by Th cells. Nussenblatt et al. reported that 
CsA provided significantly regression the acute phase of ocular attacks involving the posterior pole and significantly decreased the recurrences in the Behçet patients with severe ocular involvement and poor response to the treatment with cytotoxic agents and systemically corticosteroids $[44,45]$. Additionally, it was demonstrated that CsA decreased the Th17 and IL-17 levels in both Behçet patients [44]. It has also decreased the elevated levels of IL-17 mRNA in patients with psoriasis [47]. In our study, Th17 infiltration in the group treated with the CsA group was less than that of the sham group. It is possible that CsA suppresses Th17 by inhibiting $\mathrm{T}$ cell proliferation and cytokine synthesis. In recent studies, it was considered that CsA and metil prednisolone suppresses IL-17 level via the inhibition of NF- $\kappa B$ receptor pathway and then through IL-15 in the patients with rheumatoid arthritis [48]. Additionally, it was reported that CsA and dexamethasone to prevent Th1 and Th17 cell proliferation and consequently also decreased the synthesis of IL-17 and IFN- $\gamma$ in Vogt-Koyanagi-Harada disease $[49,50]$.

Glucocorticoids inhibit Th cells and antigen-presenting cells and the expression of cytokines such as IFN- $\gamma$, TNF- $\alpha$ and IL-2. They also reduce Th1 cytokines, and also increase the Th2 cytokines including IL-4, IL-10, IL-13 and eventually suppresses the inflammation. Thus, they have been widely used uveitis and other ocular inflammatory disease $[51,52]$. Glucocorticoids has been shown to antagonize proinflammatory effects of IL-17 [53,54]. In our study, TA significantly decreased infiltration of Th17. This is also compatible with previous reports.

As a result, Th17 is involved in the pathogenesis of uveitis. Etanercept, CsA and TA suppress Th17 proliferation and ocular inflammation in uveitis. Further studies on uveitis the treatment in animals and humans are needed to understand the exact effects of etanercept in the suppression of the inflammation.

\section{Authorship and contribution}

All authors listed on the title page made significant contributions to this manuscript.

\section{Acknowledgements}

None.

\section{Funding}

This work was funded by an unrestricted grant from Firat University Scientific Research Unit (authors' owner institution).

\section{Competing interest}

The authors have no conflict of interest or financial relationships related to this manuscript.

\section{References}

1. Ooi KG, Galatowicz G, Calder VL, Lightman SL (2006) Cytokines and chemokines in uveitis: is there a correlation with clinical phenotype? Clin Med Res 4: 294-309. [Crossref]

2. Bierly JR, Nozik RA (1992) Management of uveitis. Curr Opin Ophthalmol 3: 527533. [Crossref]

3. Gordon DM (1956) Prednisone and prednisolone in ocular disease. Am J Ophthalmol 41: 593-600.[Crossref]

4. Lustig MJ, Cunningham ET Jr (2003) Use of immunosuppressive agents in uveitis. Curr Opin Ophthalmol 14: 399-412. [Crossref]

5. Imrie FR, Dick AD (2007) Biologics in the treatment of uveitis. Curr Opin Ophthalmol 18: 481-486. [Crossref]
6. Lim L, Suhler EB, Smith JR (2006) Biologic therapies for inflammatory eye disease. Clin Experiment Ophthalmol 34: 365-374. [Crossref]

7. Takeuchi M (2013) A systematic review of biologics for the treatment of noninfectious uveitis. Immunotherapy 5: 91-102. [Crossref]

8. Sartani G, Silver PB, Rizzo LV, Chan CC, Wiggert B, et al.. (1996) Anti-tumor necrosis factor alpha therapy suppresses the induction of experimental autoimmune uveoretinitis in mice by inhibiting antigen priming. Invest Ophthalmol Vis Sci37: 22112218. [Crossref]

9. Tynjälä P, Lindahl P, Honkanen V, Lahdenne P, Kotaniemi K (2007) Infliximab and etanercept in the treatment of chronic uveitis associated with refractory juvenile idiopathic arthritis. Ann Rheum Dis 66: 548-550. [Crossref]

10. Taban M, Dupps WJ, Mandell B, Perez VL (2006) Etanercept (enbrel)-associated inflammatory eye disease: case report and review of the literature. Ocul Immunol Inflamm 14: 145-150. [Crossref]

11. Busch M, Bauer D, Hennig M, Wasmuth S, Thanos S, et al. (2013) Effects of systemic and intravitreal TNF-ÎI inhibition in experimental autoimmune uveoretinitis. Invest Ophthalmol Vis Sci 54: 39-46. [Crossref]

12. Korn T, Bettelli E, Oukka M, Kuchroo VK (2009) IL-17 and Th17 Cells. Annu Rev Immunol27: 485-517. [Crossref]

13. Amadi-Obi A, Yu CR, Liu X, Mahdi RM, Clarke GL, et al. (2007) TH17 cells contribute to uveitis and scleritis and are expanded by IL-2 and inhibited by IL-27/ STAT1. Nat Med 13: 711-718. [Crossref]

14. Chi W, Yang P, Li B, Wu C, Jin H, et al. (2007) IL-23 promotes CD4+ T cells to produce IL-17 in Vogt-Koyanagi-Harada disease. J Allergy Clin Immunol 119: 12181224. [Crossref]

15. Yoshimura T, Sonoda KH, Miyazaki Y, Iwakura Y, Ishibashi T, et al. (2008) Differential roles for IFN-gamma and IL-17 in experimental autoimmune uveoretinitis. Int Immunol 20: 209-214. [Crossref]

16. Yoshimura T, Sonoda KH, Ohguro N, Ohsugi Y, Ishibashi T, et al. (2009) Involvement of Th17 cells and the effect of anti-IL-6 therapy in autoimmune uveitis. Rheumatology (Oxford) 48: 347-354. [Crossref]

17. Cui Y, Shao H, Lan C, Nian H, O'Brien RL, et al. (2009) Major role of gamma delta $\mathrm{T}$ cells in the generation of IL-17+ uveitogenic T cells. J Immunol 183: 560-567. [Crossref]

18. Sakaguchi M, Sugita S, Sagawa K, Itoh K, Mochizuki M (1998) Cytokine production by $\mathrm{T}$ cells infiltrating in the eye of uveitis patients. Jpn J Ophthalmol 42: 262-268. [Crossref]

19. Sugita S, Takase H, Taguchi C, Mochizuki M (2007) The role of soluble TNF receptors for TNF-alpha in uveitis. Invest Ophthalmol Vis Sci 48: 3246-3252. [Crossref]

20. Starnes T, Robertson MJ, Sledge G, Kelich S, Nakshatri H, et al. (2001) Cutting edge: IL-17F, a novel cytokine selectively expressed in activated $\mathrm{T}$ cells and monocytes, regulates angiogenesis and endothelial cell cytokine production. J Immunol 167:4137. [Crossref]

21. Kolls JK, Lindén A (2004) Interleukin-17 family members and inflammation. Immunity 21: 467-476. [Crossref]

22. Er H, Uzmez E, Dogan N, Cumhurcu T (1999) Theantiinflammatory effects of nitro $\mathrm{L}$ arginine (L-NAME) and steroid in concanavalin A-induced uveitis. J Med Sci 29: 233-239.

23. Gwon A, Mantras C, Gruber L, Cunanan C (1993) Concanavalin A-induced posterior subcapsular cataract: a new model of cataractogenesis. Invest Ophthalmol Vis Sci 34: 3483-3488. [Crossref]

24. Sun M, Yang Y, Yang P, Lei B, Du L, et al. (2011) Regulatory effects of IFN-Î ${ }^{2}$ on the development of experimental autoimmune uveoretinitis in B10RIII mice. PLoS One 6: e19870. [Crossref]

25. Kawashima H, Fujino Y, Mochizuki M (1990) Antigen-specific suppressor cells induced by FK506 in experimental autoimmune uveoretinitis in the rat. Invest Ophthalmol Vis Sci 31: 2500-2507. [Crossref]

26. Luger D, Silver PB, Tang J, Cua D, Chen Z, et al. (2008) Either a Th17 or a Th1 effector response can drive autoimmunity: conditions of disease induction affect dominant effector category. J Exp Med 205: 799-810. [Crossref]

27. Abbas AK, Murphy KM, Sher A (1996) Functional diversity of helper T lymphocytes. Nature 383: 787-793. [Crossref]

28. Romagnani S (1997) The Th1/Th2 paradigm.Immunol Today 18: 263-266. [Crossref] 
29. Starnes T, Broxmeyer HE, Robertson MJ, Hromas R (2002) Cutting edge: IL-17D, a novel member of the IL-17 family, stimulates cytokine production and inhibits hemopoiesis. J Immunol 169: 642-646. [Crossref]

30. Chiricozzi A, Guttman-Yassky E, Suárez-Fariñas M, Nograles KE, Tian S, et al. (2011) Integrative responses to IL-17 and TNF-a in human keratinocytes account for key inflammatory pathogenic circuits in psoriasis. The Journal of Investigative Dermatology 131: 677-687. [Crossref]

31. Miossec P, Korn T, Kuchroo VK (2009) Interleukin-17 and type 17 helper T cells. $N$ Engl J Med 361: 888-898. [Crossref]

32. Spriggs MK (1997) Interleukin-17 and its receptor. J Clin Immunol 17: 366-369. [Crossref]

33. Broxmeyer HE (1996) Is interleukin-17, an inducible cytokine that stimulates production of other cytokines, merely a redundant player in a sea of other biomolecules. J Exp Med 183: 2411-2415. [Crossref]

34. Chi W, Zhu X, Yang P, Liu X, Lin X, et al.. (2008) Upregulated IL-23 and IL-17 in Behçet patients with active uveitis. Invest Ophthalmol Vis Sci 49: 3058-3064. [Crossref]

35. Luger D, Caspi RR (2008) New perspectives on effector mechanisms in uveitis. Semin Immunopathol 30: 135-143. [Crossref]

36. Reiff A, Takei S, Sadeghi S, Stout A, Shaham B, et al. (2001) Etanercept therapy in children with treatment-resistant uveitis. Arthritis Rheum 44: 1411-1415. [Crossref]

37. Lu TT, Zhu P, Li XY, Fan CM (2008) [Functional status of T helper cells in rheumatoid arthritis and effect of etanercept]. Xi Bao Yu Fen ZiMian Yi Xue Za Zhi 24: 495-497. [Crossref]

38. Caproni M, Antiga E, Melani L, Volpi W, Del Bianco E, et al. (2009) Serum levels of IL-17 and IL-22 are reduced by etanercept, but not by acitretin, in patients with psoriasis: a randomized-controlled trial.JClinImmunol 29: 210-214. [Crossref]

39. Zaba LC, Cardinale I, Gilleaudeau P, Sullivan-Whalen M, Suárez-Fariñas M, et al. (2007) Amelioration of epidermal hyperplasia by TNF inhibition is associated with reduced Th17 responses. J Exp Med 204: 3183-3194. [Crossref]

40. Dick AD, McMenamin PG, Korner H, Scallon BJ, Ghrayeb J, et al. (1996) Inhibition of tumor necrosis factor activity minimizes target organ damage in experimental autoimmune uveoretinitis despite quantitatively normal activated $\mathrm{T}$ cell traffic to the retina. Eur J Immunol 26: 1018-1025. [Crossref]

41. Pazderka F, Enns J, Batiuk TD, Halloran PF (1996) The functional consequences of partial calcineurin inhibition in human peripheral blood mononuclear leucocytes. Transpl Immunol 4: 23-31. [Crossref]
42. Masuda K, Nakajima A, Urayama A, Nakae K, Kogure M, et al.(1989) Double-masked trial of cyclosporin versus colchicine and long-term open study of cyclosporin in Behçet's disease.Lancet 1: 1093-1096. [Crossref]

43. Nussenblatt RB, Rodrigues MM, Salinas-Carmona MC, Gery I, Cevario S, et al.(1982) Modulation of experimental autoimmune uveitis with cyclosporin A. Arch Ophthalmol 100: 1146-1149. [Crossref]

44. Nussenblatt RB, Palestine AG, Chan CC, Mochizuki M, Yancey K (1985) Effectiveness of cyclosporin therapy for Behçet's disease. Arthritis Rheum 28: 671-679. [Crossref]

45. Nussenblatt RB, Palestine AG, Chan CC (1983) CyclosporinA therapy in the treatment of intraocular inflammatory disease resistant to systemic corticosteroids and cytotoxic agents. Am J Ophthalmol 96: 275-282. [Crossref]

46. Nussenblatt RB, Rodrigues MM, Wacker WB, Cevario SJ, Salinas-Carmona MC, et al.(1981) Cyclosporin a. Inhibition of experimental autoimmune uveitis in Lewis rats. J Clin Invest 67: 1228-1231. [Crossref]

47. Lowes MA, Kikuchi T, Fuentes-Duculan J, Cardinale I, Zaba LC, et al. (2008) Psoriasis Vulgaris Lesions Contain Discrete Populations of Th1 and Th17 T Cells. J Invest Dermatol 128:1207-1211. [Crossref]

48. Ziolkowska M, Koc A, Luszczykiewicz G, Ksiezopolska-Pietrzak K, Klimczak E, et al. (2000) High levels of IL-17 in rheumatoid arthritis patients: IL-15 triggers in vitro IL-17 production via cyclosporin A-sensitive mechanism. J Immunol 164: 2832-2838. [Crossref]

49. Liu X, Yang P, Lin X, Ren X, Zhou H, et al.(2009) Inhibitory effect of Cyclosporin A and corticosteroids on the production of IFN-gamma and IL-17 by T cells in VogtKoyanagi-Harada syndrome. Clin Immunol 131: 333-342. [Crossref]

50. Yang K, Wen J, Liu X, Kijlstra A, Chen L, et al.(2009) Inhibitory effect of rapamycin and dexamethasone on production of IL-17 and IFN-gamma in Vogt-Koyanagi-Harada patients. Br J Ophthalmol 93: 249-253. [Crossref]

51. Marchant A, Amraoui Z, Gueydan C, Bruyns C, Le Moine O, et al. (1996) Methylprednisolone differentially regulates IL-10 and tumour necrosis factor (TNF) production during murine endotoxaemia. Clin Exp Immunol 106: 91-96. [Crossref]

52. Ramírez F, Fowell DJ, Puklavec M, Simmonds S, Mason D (1996) Glucocorticoids promote a TH2 cytokine response by CD4+ T cells in vitro. J Immunol 156: 24062412. [Crossref]

53. Molet SM, Hamid QA, Hamilos DL (2003) IL-11 and IL-17 expression in nasa polyps: relationship to collagen deposition and suppression by intranasal fluticasone propionate. Laryngoscope 113:1803-1812. [Crossref]

54. Momcilovic M, Miljkovic Z, Popadic D, Markovic M, Savic E, et al. (2008) Methylprednisolone inhibits interleukin-17 and interferon-? expression by both naive and primed T cells. BMC Immunol 47:2172-2182.

Copyright: (C2016 Demir T. This is an open-access article distributed under the terms of the Creative Commons Attribution License, which permits unrestricted use, distribution, and reproduction in any medium, provided the original author and source are credited. 